\title{
Effects of gradual cooling treatment on the skin blackening and physicochemical characteristics of 'Chuhwang' pear fruit
}

\author{
Mi-Hee Choi*, Hyun Jin Choi, Seong Sig Hong, Byung-Seon Lim* \\ Postharvest Research Division, National Institute of Horticultural and Herbal Science (NIHHS), \\ RDA, Wanju 55365, Korea
}

\section{저온저장 전 온도순화처리가 추황배의 과피흑변 발생 및 생리화학적 특성에 미치는 영향:}

\author{
최미희*·최현진 · 홍성식 · 임병선* \\ 농촌진흥청 국립원예특작과학원 저장유통과
}

\begin{abstract}
'Chuhwang' pear fruit was harvested at 187 days after full bloom and stored at $0^{\circ} \mathrm{C}$ for $70 \mathrm{~d}$ after gradual cooling (GC) treatment for $20 \mathrm{~d}$. Direct cooling (DC) treatment was used as a control, and this involved direct storage at $0{ }^{\circ} \mathrm{C}$ after harvest. Following GC treatment, a weight loss of $4.62 \%$ was recorded. In addition. after $30 \mathrm{~d}$ of storage at $0{ }^{\circ} \mathrm{C}$, the incidence of skin blackening was almost completed and incidence rate in $\mathbf{G C}$ treatment significantly decreased to $\mathbf{1 3 . 9 \%}$ compared to $\mathbf{7 2 . 2 \%}$ in DC treatment. Furthermore, in term of GC treatment, the total color differences $(\Delta E)$, hardness, and sucrose contents were somewhat lower, but the electrolyte leakage rate and respiration rate were slightly higher than those of DC treatment. Moreover, the contents of hexose, ascorbic acid, and total polyphenol and DPPH radical scavenger activity were slightly higher for the GC treated samples. The activities of polyphenol oxidase and lipoxygenase and thiobarbituric acid reactive substances were low following GC treatment, and no significant differences in the antioxidant enzyme activities were observed between treatment groups. Therefore, these results indicate that the GC treatment prior to cold storage appears to inhibit skin blackening in 'Chuhwang' pear fruit by decreasing the chilling sensitivity.
\end{abstract}

Key words : 'Chuhwang' pear, skin blackening, gradual cooling, antioxidant activity

\section{서 론}

주로 생과로 소비되는 동양배(Pyrus pyrifolia Nakai)는 저온저장 시 과피흑변(skin blackening)이나 과심 및 과육 갈변(core/flesh browning) 등의 생리장해 현상이 발생한다 (Lee, 2014). 이 중 과피흑변은 저온저장 초기에 과피의 표면에 흑색 물질이 얇게 분포하며 시작되다가 저장 25 30 일 이내에 발생이 완료되며, 심한 경우에는 과실 표면의
$80-90 \%$ 까지 짙은 흑색의 반점이 형성되는 현상을 말한 다(Choi 등, 2015). 과피흑변 현상은 유전적 요인인 품종에 따른 발생의 정도가 뚜렷한 차이를 보이는데, 금촌추 및 금촌추와의 교배를 통해 육성된 신고와 추황배 등에서 주로 발생하고, 일반적으로 수확 후 저온 다습한 조건이거 나 저장 과정에서의 높은 이산화탄소 농도 등 환경적인 요인들에 의해서도 영향을 크게 받는 것으로 알려져 있다. 또한, 수확 전 수상에서도 발생하여 외관을 크게 손상시킴

*Corresponding author. Mi-Hee Choi. E-mail : truthfree@korea.kr, Phone : +82-63-238-6543, Fax : +82-63-238-6505 Byung-Seon Lim. E-mail : limbsw@korea.kr, Phone : +82-63-238-6543, Fax : +82-63-238-6505

Received 12 December 2019; Revised 29 January 2020; Accepted 20 February 2020.

Copyright (c) The Korean Society of Food Preservation.

This is an Open Access article distributed under the terms of the Creative Commons Attribution Non-Commercial License (http://creativecommons.org/licenses/by-nc/4.0) which permits unrestricted non-commercial use, distribution, and reproduction in any medium, provided the original work is properly cited. 
으로써 상품성을 저하시키는 요인이 되고 있다(Choi 등, 2013; Choi 등, 2015; Lee 등, 2018).

국내에서 신고나 추황배의 과피흑변 발생기작 구명 및 방지기술개발을 위한 연구들은 오래 전부터 보고되어 왔 으나, 아직까지 이에 대한 명확한 결론은 제시되지 못하고 있는 실정이다. 정상적인 환경조건 하에서 식물체는 세포 의 대사과정에서 hydroxyl radical $(\cdot \mathrm{OH})$, hydrogen peroxide $\left(\mathrm{H}_{2} \mathrm{O}_{2}\right)$ 및 superoxide anion $\operatorname{radical}\left(\mathrm{O}_{2}{ }^{-{ }^{-}}\right)$등과 같은 활성산 소종(reactive oxygen species, ROS)을 생성하게 되고, 생성 된 ROS는 세포기관들의 효소적, 비효소적 항산화체계에 의해 제거되면서 세포내의 항산화방어체계와 ROS 간의 균형은 유지된다(Gill과 Tuteja, 2010). 그러나 저온과 같은 환경적 요인이 스트레스로 작용하여 ROS가 과량으로 축 적되고, 세포 내부의 균형이 깨지게 되면 축적된 $\mathrm{ROS}$ 에 의해 세포막에 존재하는 지질의 과산화가 일어날 수 있고, 이로 인해 세포막의 견고성(membrane integrity)이 손상을 입게 되면 세포 내에 존재하는 polyphenol oxidase(PPO)에 의해 phenolic compounds가 산화되어 중합체를 형성함으 로써 과피의 갈변 또는 흑변과 같은 생리장해가 발생하는 것으로 알려져 있다(Kang과 Lee, 2003; Demidchik, 2015; Kou 등, 2015; Ma 등, 2017; Lee 등, 2018).

$\mathrm{ROS}$ 에 맞서는 식물의 방어체계는 크게 2가지로 요약할 수 있는데, 첫 번째는 글루타치온, 아스코르브산 및 안토시 아닌과 같은 수용성 환원물질과 베타카로틴, 비타민 $\mathrm{E}$ 와 같은 지용성 항산화물질 등에 의한 비효소적 방어 작용이 며, 두 번째는 ROS를 기질로 이용하는 항산화효소들에 의한 효소적 방어 작용이다(Imahori 등, 2008; Lim 등, 2009; Gill과 Tuteja, 2010). 대표적인 항산화효소인 superoxide dismutase(SOD)는 superoxide anion radical을 $\mathrm{H}_{2} \mathrm{O}_{2}$ 로 치환 하는 반응을 촉매하며, peroxidase(POD), catalase(CAT) 및 ascorbate peroxidase(APX)는 $\mathrm{H}_{2} \mathrm{O}_{2}$ 를 제거하는 작용을 한 다(Demidchik, 2015). 이처럼 스트레스가 없는 상태에서는 항산화방어체계의 작용에 의해 ROS는 효과적으로 조절 되지만, 저온에 민감한 식물이 저온스트레스 환경에 노출 됐을 때 항산화체계의 작용이 불충분하게 되면 과량의 $\mathrm{ROS}$ 의 축적으로 인해 산화적 손상이 발생하게 되는 것이 다(Imahori 등, 2008; Lim 등, 2009; Gill과 Tuteja, 2010; Chongchatuporn 등, 2013).

저온저장 중 발생하는 과일의 과피 갈변이나 흑변을 방지하기 위한 연구들을 보면 $\mathrm{CaCl}_{2}(\mathrm{Kou}$ 등, 2015), gamma-aminobutyric acid(GABA)(Wang 등, 2014), oxalic acid(Wang 등, 2016), 에틸렌(Ma 등, 2017) 및 1-MCP(Yu 등, 2017) 등과 같은 화학물질을 이용하거나, 예건처리(Lee 등, 2018), 열 및 열수처리(Holland 등, 2002; Kang과 Lee, 2003), 예냉처리(Yan 등, 2013), 저온컨디셔닝처리(Li 등, 2017; Zhang 등, 2017) 등과 같이 온도(열) 조건을 이용한
처리기술 등 다양한 방법들이 이용되고 있으며, 이러한 방지기술들은 근본적으로 과일의 항산화 방어체계를 강 화시킴으로써 저온에 대한 내성(chilling tolerance)을 높여 산화적 손상을 감소시키거나 방지하는 효과를 나타내는 것으로 보고되고 있다.

따라서 본 연구는 과피흑변 현상이 주로 저온저장 시 발생하는 것에 초점을 맞추어 저온저장 전 온도순화처리 가 추황배의 저온내성에 미치는 영향과 저온저장 중 과피 흑변 발생률, 비효소적 및 효소적 항산화방어기작과 관련 된 요인들의 변화를 분석하여 이에 따른 과피흑변 발생 저감화 기술을 제시하고자 하였다.

\section{재료 및 방법}

\section{시료 및 시험처리}

본 실험에 사용한 추황배는 2018년 전라남도 나주지역에 서 생산된 것으로 추황배 전용봉지인 백황지(Seungiljedae Inc., Yeongcheon, Korea)를 씨워 재배하였으며, 만개 후 187 일(2018년 10월 15일)에 수확하여 상온에 12시간 보관 후 선별하여 실험에 사용하였다. 온도순화처리구(gradual cooling treatment, $\mathrm{GC})$ 는 선별 후 배봉지를 씨워 $20^{\circ} \mathrm{C}, 15^{\circ} \mathrm{C}$, $12^{\circ} \mathrm{C}, 9^{\circ} \mathrm{C}, 6^{\circ} \mathrm{C}$ 순서로 각각 3 일씩 처리하면서 15 일간 점차 적으로 온도를 내렸고, 이후 $5^{\circ} \mathrm{C}$ 에서 $1{ }^{\circ} \mathrm{C}$ 까지는 하루에 $1{ }^{\circ} \mathrm{C}$ 씩 온도를 내리면서 5 일간 처리하였다. 온도순화처리 기간은 총 20 일이 소요되었으며, 처리 종료 후에는 $0^{\circ} \mathrm{C}$ 에 저장하였다. 대조구는 선별 후 $0^{\circ} \mathrm{C}$ 에 바로 저장 (direct cooling treatment, DC)하였다. 대조구와 온도순화처리구 모두 저장 시 배봉지를 제거한 다음 필름 내 결로현상을 최소화하기 위해 흡습지(특수지코팅페이퍼, $450 \times 720 \mathrm{~mm}$, 대한특수제지, 파주, 한국)를 넣고, 미세천공필름(micro perforated PE film, 550×850 mm, Taebang Patec Co., LTD., Yangju, Korea)으로 포장한 후 $0^{\circ} \mathrm{C}$ 저장고에서 70 일간 저장 하면서 과실품질 및 이화학적 특성변화를 조사하였다. 저 장기간 동안 필름 내부의 온도와 상대습도는 각각 $0.9 \pm 0.5^{\circ} \mathrm{C}, 99.8 \pm 0.5 \%$ 로 유지되었다.

시약

총폴리페놀 함량 분석 및 항산화 활성 분석용 추출용매 인 methanol은 J.T.Baker(Mallinckrodt Baker Inc., Phillipsburg, NJ, USA) 제품을 이용하였으며, 적정산도 측정용 $0.1 \mathrm{~N} \mathrm{NaOH}$ 는 대정화금(Siheung, Korea), mannitol, sucrose, fructose, glucose, sorbitol, trichloroacetic acid(TCA), DLdithiothreitol, N-ethylmaleimide, orthophosphoric acid, 2,2bipyridyl, ferric chloride $\left(\mathrm{FeCl}_{3}\right)$, L-ascorbic acid, FolinCiocalteu's phenol 시약, $\mathrm{Na}_{2} \mathrm{CO}_{3}$, chlorogenic acid, $\mathrm{Na}_{2} \mathrm{HPO}_{4}$, $\mathrm{NaH}_{2} \mathrm{PO}_{4}$ EDTA-Na, $\mathrm{K}_{2} \mathrm{HPO}_{4}, \mathrm{KH}_{2} \mathrm{PO}_{4}, \mathrm{H}_{2} \mathrm{O}_{2}$, phenylme- 
thylsulfonyl fluoride(PMSF), polyvinylpyrrolidone(PVP), citric acid, catechol, bovine serum albumin(BSA), 2,2-diphenyl-2-picrylhydrazyl(DPPH), trolox, 2-thiobarbituric acid(TBA), linoleic acid, riboflavin, nitroblue tetrazolium (NBT), methionine, guaiacol은 모두 Sigma-Aldrich(Sigmaaldrich Inc., St. Louis, MO, USA) 제품을 이용하였다.

\section{과피흑변 발생률 조사}

처리구별로 품질조사 시료와는 별도로 각각 2세트(1세 $\underline{E}=20$ 개 추황배)의 과피흑변 조사 시료를 준비하였으며, 품질조사기간에 맞춰 과피흑변 발생률을 조사하였다. 과 피흑변 발생률(\%)은 세트별로 20 개에 대한 과피흑변 발생 과의 비율로 계산하였으며, 최종 결과는 2세트의 과피흑변 발생률의 평균값으로 나타냈다.

\section{품질특성 변화 조사}

중량감소율은 초기 중량을 기준으로 저장 기간에 따른 중량감소를 백분율 $(\%)$ 로 나타내었고, 과피의 총색차(total color difference, $\Delta \mathrm{E})$ 는 처리구별 5 개의 시료를 택하여 과실 의 적도부위 3 군데를 색차계(CR-400, Konica Minolta Corp., Tokyo, Japan)의 광조사 부분에 밀착시켜 측정하여 얻은 L값, $\mathrm{a}$ 값, $\mathrm{b}$ 값을 이용하여 계산하였다. 경도(hardness) 는 Texture Analyzer(TA plus, Lloyd Instrument Ltd. Godalming, UK)를 이용하여 과피를 제거하지 않은 상태에 서 $5 \mathrm{~mm}$ cylindrical probe로 변형 깊이 $10 \mathrm{~mm}$, 침투 속도 $100 \mathrm{~mm} / \mathrm{min}$ 로 총 5 개의 배에서 과실의 적도부위 2 군데를 측정하여 평균값 $(\mathrm{N})$ 으로 나타내었다. 가용성 고형물 함량 은 과실의 6 부위에서 과육과 과피를 절단하여 착즙기 (FruX80, Goojung engineering, Seoul, Korea)로 가압 착즙한 후 굴절당도계(Model RA-520N, KEM Co., Ltd. Kyoto, Japan)로 측정하여 ${ }^{\circ} \mathrm{Brix}$ 로 나타내었다. 적정산도(titratable acidity, TA)는 $\mathrm{pH}$ 적정기(Orion Star A211, Thermo electron Corp., Waltham, MA, USA)를 이용하여 착즙액 $5 \mathrm{~mL}$ 에 증류수 $20 \mathrm{~mL}$ 를 첨가해 희석한 후 $0.1 \mathrm{~N} \mathrm{NaOH}$ 용액으로 $\mathrm{pH} 8.2$ 까지 적정하여 $\mathrm{NaOH}$ 소비량 $(\mathrm{mL})$ 을 malic acid\%로 환산하여 표시하였다. 호흡량은 $1.4 \mathrm{~L}$ 용기에 배 1 개씩을 넣고 $0^{\circ} \mathrm{C}$ 에서 1 시간 동안 밀폐시킨 후 $1 \mathrm{~mL}$ 의 공기를 취하 여 열전도성 검출기(thermal conductivity detector)를 장착 한 $\mathrm{GC}($ Varian 450, Scion Instruments, Scotland, UK)로 이산 화탄소 발생량을 측정하여 나타냈으며, 분석조건은 active carbon packed column $\left(2 \mathrm{M} \times 1 / 8^{\prime \prime} \times 2.0 \mathrm{~mm}\right)$, injector, oven 및 detector의 온도는 각각 $150^{\circ} \mathrm{C}, 80^{\circ} \mathrm{C}$ 및 $150^{\circ} \mathrm{C}$, 이동상인 헬륨가스의 유속은 $60 \mathrm{~mL} / \mathrm{min}$ 이었다.

\section{전해질 유출률 (electrolyte leakage rate) 조사}

전해질유출률은 $\mathrm{Ma}$ 등(2017)의 방법을 약간 변형하여
측정하였다. 각 과실에서 6 개의 $\operatorname{disk}(\oint 10 \mathrm{~mm} \times 5 \mathrm{~mm}, 2.0 \pm$ $0.1 \mathrm{~g}$ )를 취하여 시험관에 넣고 $0.4 \mathrm{M}$ mannitol 용액으로 3 회 세척한 후, $20 \mathrm{~mL} 0.4 \mathrm{M}$ mannitol 용액을 넣어 $20^{\circ} \mathrm{C}$ 에 서 2시간 반응 후에 전도도측정기(Orion 4-Star, Thermo electron Corp., Waltham, MA, USA)를 이용하여 전도도 $\left(\mathrm{C}_{\text {time }}\right)$ 를 측정하였다. 총전도도 $\left(\mathrm{C}_{\mathrm{total}}\right)$ 는 $121^{\circ} \mathrm{C}$ 에서 15 분간 autoclave(Bionex VS-1221, Vision scientific Co., LTD., Daejeon, Korea)로 가열한 다음 상온까지 식힌 후 측정하였 으며, 전해질 유출률의 계산식은 다음과 같다.

전해질유출률 $(\%$ of total $)=\left(\mathrm{C}_{\text {time }} / \mathrm{C}_{\text {total }}\right) \times 100$

\section{수용성 탄수화물(soluble carbohydrates) 및 총 아스코르브산 함량 분석}

과피를 제거한 과육 $10 \mathrm{~g}$ 에 $30 \mathrm{~mL}$ 의 3 차 증류수를 넣고 균질기(T25, IKA Labortechnik, Germany)로 분쇄하여 $4{ }^{\circ} \mathrm{C}$ 에서 $25,000 \times g$ 로 20 분간 원심분리(Labogene 2236R, Gyrogen, Daejeon, Korea)하였다. 상등액은 Sep-pak $\mathrm{C}_{18}$ (Waters, Milford, MA, USA)과 $0.45 \mu \mathrm{M}$ PVDF syringe filter (Whatman, Little Chalfont, UK)로 여과한 후 $\operatorname{HPLC}(1260$ Infinity II series, Agilent Technologies, Santa Clara, CA, USA)로 분석하였다. 칼럼은 Waters sugar pack I과 Waters guard pack을 함께 사용하였으며, 시료 주입량은 $20 \mu \mathrm{L}$, oven 온도는 $80^{\circ} \mathrm{C}$, 이동상은 $0.1 \mathrm{mM} \mathrm{Ca-EDTA용액,} \mathrm{유속은}$ $0.5 \mathrm{~mL} / \mathrm{min}$ 으로 하였다. 표준물질로는 sucrose, fructose, glucose, sorbitol을 사용하였으며, 유리당별로 표준곡선 $\left(\mathrm{R}^{2}\right.$ $\geq 0.998$ )을 작성하여 정량하였다.

과피의 총아스코르브산 함량은 Murshed 등(2013)의 방 법에 따라 추황배 과피 $3 \mathrm{~g}$ 을 $12 \mathrm{~mL}$ 의 $6 \%$ iced trichloroacetic $\operatorname{acid}(\mathrm{TCA})$ 로 추출한 후 $4^{\circ} \mathrm{C}$ 에서 $25,000 \times g$ 로 20 분 간 원심분리(Labogene 2236R, Gyrogen)하여 얻은 상등액 을 이용하여 분석하였다. $0.05 \mathrm{~mL}$ 의 추출액에 $0.05 \mathrm{~mL}$ $10 \mathrm{mM}$ DL-dithiothreitol과 $0.1 \mathrm{~mL} 0.2 \mathrm{mM}$ sodium phosphate buffer(pH 7.4)를 넣고 $42^{\circ} \mathrm{C}$ 에서 15 분간 반응시킨 후 0.05 $\mathrm{mL} 0.5 \%$ N-ethylmaleimide를 넣어주고, 1 분 뒤 반응액 $(0.25$ $\mathrm{mL} \mathrm{10 \%} \mathrm{TCA,} 0.2 \mathrm{~mL} 42 \%$ orthophosphoric acid, $0.2 \mathrm{~mL}$ $4 \%$ 2,2-bipyridyl, $0.1 \mathrm{~mL} 3 \%$ ferric chloride)을 첨가하여 $42^{\circ} \mathrm{C}$ 에서 40 분간 반응시키고, 분광광도계(Epoch2, Biotek Instrument, Inc., Winooski, VT, USA)를 이용하여 $525 \mathrm{~nm}$ 에 서 흡광도를 측정하였다. 표준물질은 L-ascorbic acid를 사 용하였다.

\section{총폴리페놀 함량(total polyphenol content) 및 polyphenol oxidase(PPO) 활성 분석}

총폴리페놀 함량 분석은 추황배 과피 $3 \mathrm{~g}$ 에 $15 \mathrm{~mL} \mathrm{70 \%}$ methanol을 넣고 균질기(T25, IKA)로 분쇄하여 2시간동안 
초음파추출(RK510H, Bandelin Electronic Co., Berlin, Germany) 후 $4^{\circ} \mathrm{C}$ 에서 $25,000 \times g$ 로 20 분간 원심분리 (Labogene 2236R, Gyrogen)하여 얻은 상등액을 이용하였 으며, $\operatorname{Kim}(2009)$ 등의 방법을 일부 변형하여 수행하였다. $0.1 \mathrm{~mL}$ 추출액과 $0.4 \mathrm{~mL} 0.2 \mathrm{~N}$ Folin-Ciocalteu's phenol 시약 을 3분간 반응시키고 $0.8 \mathrm{~mL} 10 \% \mathrm{Na}_{2} \mathrm{CO}_{3}$ 을 첨가하여 상온 에서 1시간 반응 후 마이크로 플레이트 리더(Epoch2, Biotek Instrument, Inc.,)를 이용하여 $700 \mathrm{~nm}$ 에서 흡광도를 측정하였다. 표준곡선은 chlorogenic acid를 이용하여 작성 하였으며, 이로부터 생체중량 $1 \mathrm{~g}$ 에 대한 $\mathrm{mg}$ chlorogenic acid equivalent(CAE)를 구하였다.

Polyphenol oxidase(PPO)활성 분석을 위한 조효소추출 액은 과피 $3 \mathrm{~g}$ 에 $2 \mathrm{mM}$ EDTA- $\mathrm{Na}, 1 \mathrm{mM}$ phenylmethylsulfonyl fluoride(PMSF), 1\% polyvinylpyrrolidone(PVP) 를 첨가한 $15 \mathrm{~mL} 100 \mathrm{mM}$ potassium phosphate buffer $(\mathrm{pH}$ 7.5 )를 넣고 균질화한 후 $4^{\circ} \mathrm{C}, 25,000 \times g$ 로 20 분간 원심분리 (Labogene 2236R, Gyrogen)하여 얻은 상등액을 이용하였 다. $\mathrm{PPO}$ 활성은 $10 \mu \mathrm{L}$ 조효소액과 $500 \mu \mathrm{L}$ 증류수, 500 $\mu \mathrm{L}$ 반응액 $\left(2.84 \% \quad \mathrm{Na}_{2} \mathrm{HPO}_{4}, 2.1 \%\right.$ citric acid, $1.104 \%$ catechol 혼합액)을 혼합한 후 $420 \mathrm{~nm}$ 에서 30 초 간격으로 5 분간 흡광도 변화를 측정하였으며, 1 분에 흡광도가 1 증 가하는 것을 1 unit으로 하였으며, 효소의 활성은 unit $/ \mathrm{mg}$ protein으로 나타냈다. 모든 효소의 분석 시 단백질 정량은 bovine serum albumin(BSA)를 표준물질로 사용하여 Bradford 방법(Zor와 Selinger, 1996)에 따라 수행하였다.

\section{2,2-Diphenyl-2-picrylhydrazyl(DPPH) radical scavenger activity 분석}

추황배 과피의 항산화 활성은 DPPH 라디칼 소거능으로 평가하였으며(Kim 등, 2009), 과피 $3 \mathrm{~g}$ 에 $15 \mathrm{~mL} \mathrm{70 \%}$ methanol을 넣고 균질화하여 30 분간 초음파추출(RK510H, Bandelin Electronic Co.)한 후 $4^{\circ} \mathrm{C}, 25,000 \times g$ 로 20 분간 원심 분리(Labogene 2236R, Gyrogen)하여 얻은 상등액을 이용 하였다. $0.2 \mathrm{~mL}$ 추출액과 $0.8 \mathrm{~mL} 300 \mu \mathrm{M} \mathrm{DPPH}$ 용액을 혼합하여 상온에서 20 분간 반응시킨 후 마이크로 플레이 트 리더(Epoch2, Biotek Instrument, Inc.)를 이용하여 515 $\mathrm{nm}$ 에서 흡광도를 측정하였으며, 라디칼 소거능은 Trolox 표준곡선을 이용하여 생체중량 $1 \mathrm{~g}$ 에 대한 $\mu \mathrm{mol}$ Trolox equivalent(TE)로 나타냈다.

\section{지질과산화물(TBARS) 및 lipoxygenase(LOX) 활성 분석}

Thiobarbituric acid reactive substances(TBARS) 함량은 Wang 등(2018)의 방법을 일부 변형하여 분석하였다. 과피 $3 \mathrm{~g}$ 에 $12 \mathrm{~mL} 6 \% \mathrm{TCA}$ 용액을 넣고 균질화하여 추출한 후 $25,000 \times g$ 로 20분간 원심분리(Labogene 2236R, Gyrogen)하
였다. 상등액과 $0.67 \%$ 2-thiobarbituric acid(TBA)를 동일 비 율(v:v)로 혼합하여 $121^{\circ} \mathrm{C}$ 에서 15 분간 고압살균 후 즉시 얼 음물에서 냉각하여 $450,532,600 \mathrm{~nm}$ 에서 흡광도를 측정하 였으며, 다음의 식을 이용하여 TBARS 함량을 계산하였다.

TBARS 함량 $(\mu \mathrm{mol} / \mathrm{g} \mathrm{FW})$

$$
\begin{aligned}
= & \left\{6.45 \times\left(\mathrm{A}_{532}-\mathrm{A}_{600}\right)-0.56 \times \mathrm{A}_{450}\right\} \times(\mathrm{a} / \mathrm{b}) \\
& \mathrm{a}: \text { 추출액의 양 }(\mathrm{mL}) \\
& \mathrm{b}: \text { 시료 중량 }(\mathrm{g})
\end{aligned}
$$

$\mathrm{LOX}$ 분석용 조효소액은 $\mathrm{PPO}$ 분석용과 동일하게 추출 하였으며, LOX 활성은 Lin 등(2016)의 방법을 일부 변형하 여 측정하였다. $30 \mu \mathrm{L}$ 조효소액에 $720 \mu \mathrm{L} 50 \mathrm{mM}$ sodium phosphate buffer(pH 7.0), $3 \mu \mathrm{L} 10 \mathrm{mM}$ linoleic acid를 혼합한 후 $234 \mathrm{~nm}$ 에서 3 분간 30 초 간격으로 흡광도 변화를 측정하 였다. 1 unit은 1 분에 흡광도가 0.01 증가하는 것으로 정의 하였으며, 효소의 활성은 unit/mg protein으로 나타냈다.

\section{항산화 관련 효소의 활성 분석}

항산화 효소 분석을 위한 조효소추출과 단백질 정량은 $\mathrm{PPO}$ 분석에서 기술한 방법과 동일하며, 항산화 효소의 활성은 Ma 등(2017)과 Lechaudel 등(2013)의 방법을 일부 변형하거나 상호 보완하여 측정하였다. CAT 활성은 100 $\mu \mathrm{L}$ 조효소액과 $1 \mathrm{~mL} 100 \mathrm{mM}$ potassium phosphate buffer (pH 7.5), $500 \mu \mathrm{L} 100 \mathrm{mM} \mathrm{H}_{2} \mathrm{O}_{2}$ 를 충분히 혼합한 후 석영큐 벳을 이용하여 $240 \mathrm{~nm}$ 에서 3 분간 30 초 간격으로 흡광도 변화를 측정(Epoch2, Biotek Instrument, Inc.)하였으며, 1 unit은 1 분에 흡광도가 0.01 감소하는 것으로 정의하였다. $\mathrm{SOD}$ 활성은 $100 \mu \mathrm{L}$ 조효소액과 $500 \mu \mathrm{L} 100 \mathrm{mM}$ potassium phosphate buffer(pH 7.5), $200 \mu \mathrm{L} 2 \mu \mathrm{M}$ riboflavin, $200 \mu \mathrm{L}$ $10 \mu \mathrm{M}$ EDTA-Na $a_{2}, 200 \mu \mathrm{L} 150 \mu \mathrm{M}$ nitroblue tetrazolium (NBT), $200 \mu \mathrm{L} 13 \mathrm{mM}$ methionine을 충분히 혼합한 후 청색 광(CN-T96, ProDean, Seoul, Korea) 아래서 15분간 반응시 킨 것과 대조구(청색광에 노출시키지 않은 것)로 나누어 $560 \mathrm{~nm}$ 에서 흡광도를 측정하였으며, $\mathrm{NBT}$ 의 환원에 의해 유도되는 SOD 활성을 $50 \%$ 저해하는 효소의 양을 1 unit으 로 정의하였다. $\mathrm{APX}$ 활성은 $100 \mu \mathrm{L}$ 조효소액과 $880 \mu \mathrm{L}$ $100 \mathrm{mM}$ potassium phosphate buffer(pH 7.5), $10 \mu \mathrm{L} 50 \mathrm{mM}$ ascorbic acid, $10 \mu \mathrm{L} 10 \mathrm{mM} \mathrm{H}_{2} \mathrm{O}_{2}$ 를 혼합한 후 $290 \mathrm{~nm}$ 에서 2 분간 30 초 간격으로 흡광도 변화를 측정하였으며, 1 분에 흡광도가 0.1 감소하는 것을 1 unit으로 정의하였다. POD 활성은 $50 \mu \mathrm{L}$ 조효소액과 $700 \mu \mathrm{L} 10 \mathrm{mM}$ potassium phosphate buffer(pH 7.0), $100 \mu \mathrm{L} 20 \mathrm{mM}$ guaiacol, $40 \mu \mathrm{L}$ $40 \mathrm{mM} \mathrm{H}_{2} \mathrm{O}_{2}$ 를 충분히 혼합한 후 $470 \mathrm{~nm}$ 에서 3 분간 30 초 간격으로 흡광도 변화를 측정하였으며, 1 unit은 1 분에 흡 광도가 0.01 증가하는 것으로 정의하였다. 모든 항산화 효소의 활성은 unit $/ \mathrm{mg}$ protein으로 나타냈다. 


\section{통계분석}

시험결과의 통계처리는 SAS Enterprise Guide 7.1(SAS Institute Inc., Cary, NC, USA)를 사용하여 저장기간에 따른 차이는 일원분산분석(One-way ANOVA) 및 Duncan's multiple range test $(\mathrm{p}<0.05)$ 로 유의성을 검정하였으며, 처리 방법에 따른 차이는 student's t-test $(\mathrm{p}<0.05, \mathrm{p}<0.01)$ 로 유의 성을 검정하였다. 모든 분석은 5 반복으로 하였으며, 결과 는 평균표준오차로 나타냈다.

\section{결과 및 고찰}

\section{과피흑변 발생률}

온도순화처리에 따른 추황배의 과피흑변 발생은 유의 적으로 감소하였다. 추황배를 수확하여 상온 $\left(20 \pm 1^{\circ} \mathrm{C}\right)$ 조건 에서 12 시간 후 $0^{\circ} \mathrm{C}$ 에 바로 저장한 대조구의 경우, 저장 30 일에 과피흑변 발생률이 $72.2 \%$ 로 높게 나타났으며(Fig. $1 \mathrm{~A})$, 발생 범위 또한 과피 전체에 넓게 분포되어 있는 것을 관찰할 수 있었다(Fig. 1B). 그러나 수확 후 단계적으로 온도를 감소시킨 후 $0^{\circ} \mathrm{C}$ 에 저장한 온도순화처리구에서는
저온저장 30 일 경과 후 $13.9 \%$ 의 낮은 과피흑변 발생률을 보였으며, 과피흑변의 발생 범위 또한 매우 미미(Fig. 1C) 하게 나타나 저온저장 전 온도순화처리가 추황배의 과피 흑변 발생을 억제하는 데 효과적인 것으로 나타났다. 과피 흑변은 금촌추 유래 품종인 추황배를 비롯하여 신고배에 서도 발생하는 생리장해로, 위의 결과와 같이 과실을 저온 저장했을 때 저장 초기에 흑변발생과가 결정되고, 이들 중에서 집중적으로 발생하며, 그 이후에는 흑변 부위가 서서히 확대되는 것으로 알려져 있다(Lee, 2014). 과피흑변 발생을 억제하기 위한 다양한 연구들 중 Kang과 Lee(2003) 는 신고배를 대상으로 $48^{\circ} \mathrm{C}$ 에서 3 시간 동안 건열처리 후 $00^{\circ} \mathrm{C}$ 에 저장했을 때 과피흑변 발생이 효과적으로 억제되었 다고 보고하였으며, Lee 등(2018)은 수확한 추황배를 $20^{\circ} \mathrm{C}$ 에서 6 일간 예건처리하고, 6 일에 걸쳐 $1^{\circ} \mathrm{C}$ 까지 온도를 서 서히 떨어뜨린 후 저장하였을 때 과피흑변 발생이 유의적 으로 감소하였다고 보고하였다. 따라서 본 연구의 온도순 화처리를 포함하여 저온저장 전 온도조건을 이용한 처리 는 과피흑변 발생을 효과적으로 억제시키는 방법이 될 수 있을 것으로 판단된다.

(A)

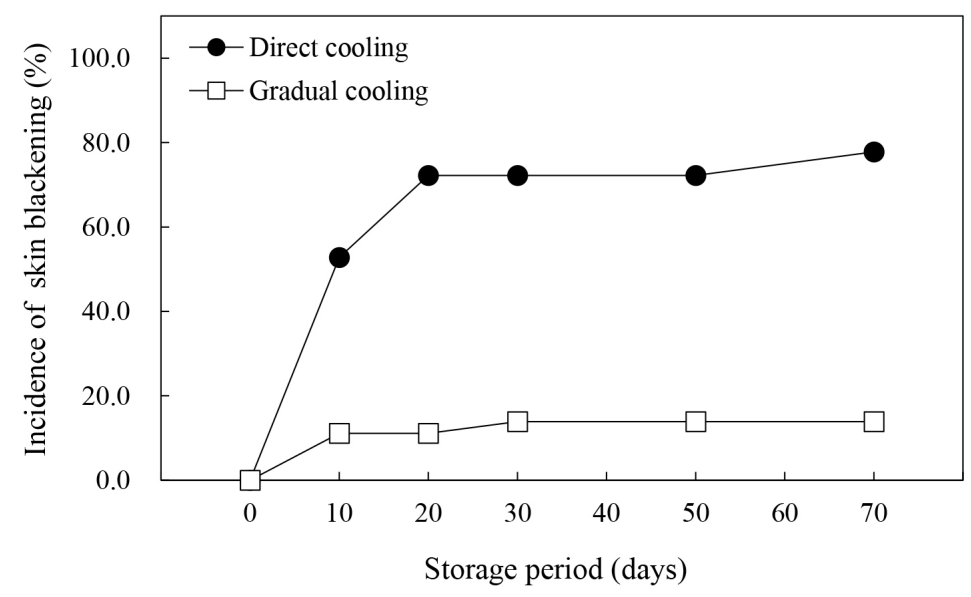

(B)

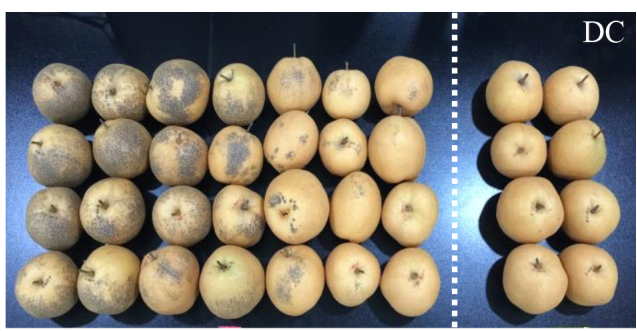

(C)

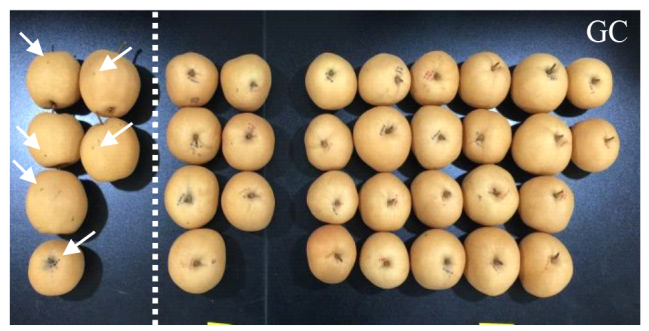

Fig. 1. The incidence of skin blackening in direct cooling (DC) and gradual cooling (GC) treated 'Chuhwang' pear fruit during 70 days of storage at $0{ }^{\circ} \mathrm{C}$.

(A) Incidence rate of skin blackening; (B) and (C) Skin blackened pear fruits according to treatments after 70 days of storage at $0^{\circ} \mathrm{C}$. 


\section{온도순화처리에 따른 품질특성 변화}

온도순화처리에 따른 품질특성 변화는 Table 1과 같다. 추황배의 중량 감소율은 저장기간에 따라 유의적으로 증 가하는 경향을 보였다 $(\mathrm{p}<0.05)$. 대조구는 저장 70 일 경과 후 $3.17 \%$ 의 중량감소를 나타냈으며, 저장 전 처리단계에 서 $4.62 \%$ 의 중량감소를 보였던 온도순화처리구는 $0{ }^{\circ} \mathrm{C}$ 저 온저장 70 일 후 $2.14 \%$ 의 추가적인 중량감소가 발생하여 총 $6.76 \%$ 의 중량감소를 나타냈다. 저온저장 중 과피의 총 색차 (delta $\mathrm{E}, \Delta \mathrm{E}$ )는 대조구와 온도순화처리 모두 저장 10 일에 각각 $2.31 \pm 0.29,2.72 \pm 0.29$ 로 크게 증가하였으며, 이 후로 대조구는 저장 기간에 따라 다소 증가하는 경향을 보여 저장 70 일에 $3.23 \pm 0.75$ 를 나타낸 반면, 온도순화처리 구는 유의미한 차이를 보이지 않았다. 이렇듯 처리간의 차이를 나타내는 것은 온도순화처리 과정에서 과피의 색 변화가 거의 다 완료되었기 때문으로 보이며, 이러한 delta $\mathrm{E}$ 값의 변화는 $\mathrm{L}$ 값, $\mathrm{b}$ 값의 변화보다는 $\mathrm{a}$ 값의 증가에 따른 것으로 나타났다(data not shown). 저장 기간에 따른 추황배 의 경도는 대조구의 경우 저장 20 일까지는 증가하다가 저장 30 일 이후 감소하였고 $(\mathrm{p}<0.05)$, 온도순화처리구의 경 도는 대조구보다 다소 낮게 나타났으며, 저장 기간의 경과 에 따른 유의적인 변화는 보이지 않았다. 이러한 경도감소 는 수분손실에 의한 중량감소뿐만 아니라, 저온저장에 따 른 저온 스트레스에 대응하는 항상성 기작의 하나로 호흡 량이 증가하면서 발생된 세포벽의 연화 및 수용성 당류의
변화에 기인한 것으로 판단된다(Park과 Lee, 2006). 수확 시 $13.28{ }^{\circ} \mathrm{Brix}$ 였던 가용성 고형물 함량은 온도순화처리 후 저온저장 10 일에 $14.26^{\circ} \mathrm{Brix}$, 저장 70 일에는 $15.38^{\circ} \mathrm{Brix}$ 까지 유의적으로 증가하였으며, 산 함량은 $0.15-0.17 \%$ 정도로 유지되어 큰 변화를 보이지 않았다. 대조구의 경우, 가용성 고형물 함량은 저장기간이 길어질수록 다소 증가 하기는 했으나 유의적인 차이는 없었으며, 산 함량은 초기 값과 큰 차이를 보이지 않았던 온도순화처리구와는 달리 감소하는 경향을 보였다( $\mathrm{p}>0.05)$.

호흡량의 변화를 보면 대조구는 저장 20 일까지는 일시 적으로 증가했다가 저장 기간이 경과함에 따라 감소한 반면, 온도순화처리구는 저장기간이 경과함에 따라 호흡 량이 서서히 증가하는 경향을 보였다. 이는 Lafta와 Fugate (2009)가 사탕무를 대상으로 한 실험에서 설명한 바와 같 이 저장 중 낮은 상대습도조건에서 건조(dehydration)에 의한 중량감소가 일어나면 식물체는 대사적 붕괴(metabolic disruption)를 겪게 되고, 이 과정에서 발생하는 ROS 로 인해 세포막의 손상(membrane damage)이 발생하면서 호흡량이 증가하게 되는데, 본 실험에서도 온도순화처리 에 의한 중량감소가 저장 중 호흡량의 증가를 가져왔을 것으로 보인다. 이상의 품질특성 변화를 종합하여 봤을 때, 과피흑변 발생 방지를 위한 저온저장 전 온도순화처리 는 추황배의 식미특성에 부정적인 영향 없이 적용할 수 있는 기술로 판단된다.

Table 1. Changes of quality characteristics in direct cooling and gradual cooling treated 'Chuhwang' pear fruit during 70 days of storage at $0^{\circ} \mathrm{C}$

\begin{tabular}{|c|c|c|c|c|c|c|c|}
\hline Treatment & $\begin{array}{c}\text { Storage } \\
\text { period (days) }\end{array}$ & $\begin{array}{l}\text { Weight loss } \\
(\%)\end{array}$ & $\begin{array}{c}\text { Total color } \\
\text { difference }(\Delta \mathrm{E})\end{array}$ & $\begin{array}{l}\text { Hardness } \\
\text { (N) }\end{array}$ & $\begin{array}{c}\text { Soluble solid } \\
\left.\text { content ( }{ }^{\circ} \text { Brix }\right)\end{array}$ & $\begin{array}{c}\text { Titratable acidity } \\
(\%)\end{array}$ & $\begin{array}{l}\text { Respiration rate } \\
(\mathrm{mg} / \mathrm{kg} / \mathrm{h})\end{array}$ \\
\hline \multirow{6}{*}{$\begin{array}{l}\text { Direct } \\
\text { Cooling } \\
\text { (DC) }\end{array}$} & 0 & $0.00 \pm 0.00^{\mathrm{E}}$ & $0.00 \pm 0.00^{\mathrm{B}}$ & $27.21 \pm 0.53^{\mathrm{AB}}$ & $13.28 \pm 0.38^{\mathrm{A}}$ & $0.16 \pm 0.01^{\mathrm{A}}$ & $7.33 \pm 0.23^{\mathrm{A}}$ \\
\hline & 10 & $0.85 \pm 0.10^{\mathrm{D}}$ & $2.31 \pm 0.29^{\mathrm{A}}$ & $27.51 \pm 0.59^{\mathrm{AB}}$ & $13.66 \pm 0.26^{\mathrm{A}}$ & $0.16 \pm 0.01^{\mathrm{A}}$ & $2.62 \pm 0.28^{\mathrm{B}}$ \\
\hline & 20 & $0.97 \pm 0.10^{\mathrm{D}}$ & $2.24 \pm 0.13^{\mathrm{A}}$ & $28.97 \pm 0.65^{\mathrm{A}}$ & $13.65 \pm 0.22^{\mathrm{A}}$ & $0.18 \pm 0.01^{\mathrm{A}}$ & $3.38 \pm 0.12^{\mathrm{B}}$ \\
\hline & 30 & $1.32 \pm 0.15^{\mathrm{C}}$ & $3.12 \pm 0.87^{\mathrm{A}}$ & $25.54 \pm 0.40^{\mathrm{B}}$ & $14.21 \pm 0.57^{\mathrm{A}}$ & $0.16 \pm 0.02^{\mathrm{A}}$ & $3.02 \pm 0.29^{\mathrm{B}}$ \\
\hline & 50 & $2.12 \pm 0.12^{\mathrm{B}}$ & $3.32 \pm 0.54^{\mathrm{A}}$ & $25.96 \pm 1.02^{\mathrm{B}}$ & $14.52 \pm 0.45^{\mathrm{A}}$ & $0.15 \pm 0.01^{\mathrm{A}}$ & $2.91 \pm 0.31^{\mathrm{B}}$ \\
\hline & 70 & $3.17 \pm 0.20^{\mathrm{A}}$ & $3.23 \pm 0.75^{\mathrm{A}}$ & $25.64 \pm 0.70^{\mathrm{B}}$ & $14.80 \pm 0.44^{\mathrm{A}}$ & $0.14 \pm 0.01^{\mathrm{A}}$ & $2.91 \pm 0.12^{\mathrm{B}}$ \\
\hline \multirow{6}{*}{$\begin{array}{c}\text { Gradual } \\
\text { Cooling } \\
\text { (GC) }\end{array}$} & 0 & $4.62 \pm 0.21^{\mathrm{c}}$ & $0.00 \pm 0.00^{\mathrm{b}}$ & $27.21 \pm 0.53^{\mathrm{a}}$ & $13.28 \pm 0.38^{\mathrm{b}}$ & $0.16 \pm 0.01^{\mathrm{a}}$ & $7.33 \pm 0.23^{\mathrm{a}}$ \\
\hline & 10 & $4.69 \pm 0.33^{\mathrm{c}}$ & $2.72 \pm 0.29^{\mathrm{a}}$ & $25.88 \pm 0.98^{\mathrm{ab}}$ & $14.26 \pm 0.12^{\mathrm{ab}}$ & $0.17 \pm 0.02^{\mathrm{a}}$ & $2.70 \pm 0.24^{\mathrm{b}}$ \\
\hline & 20 & $5.48 \pm 0.40^{\mathrm{bc}}$ & $2.99 \pm 1.03^{\mathrm{a}}$ & $25.62 \pm 0.69^{\mathrm{ab}}$ & $14.66 \pm 0.38^{\mathrm{ab}}$ & $0.17 \pm 0.02^{\mathrm{a}}$ & $2.90 \pm 0.08^{\mathrm{b}}$ \\
\hline & 30 & $5.37 \pm 0.20^{\mathrm{c}}$ & $2.48 \pm 0.42^{\mathrm{a}}$ & $25.32 \pm 1.01^{\mathrm{ab}}$ & $15.14 \pm 0.36^{\mathrm{a}}$ & $0.15 \pm 0.01^{\mathrm{a}}$ & $3.13 \pm 0.11^{\mathrm{b}}$ \\
\hline & 50 & $6.31 \pm 0.25^{\mathrm{ab}}$ & $2.27 \pm 0.40^{\mathrm{a}}$ & $25.32 \pm 0.51^{\mathrm{ab}}$ & $14.59 \pm 0.30^{\mathrm{ab}}$ & $0.16 \pm 0.02^{\mathrm{a}}$ & $3.29 \pm 0.42^{\mathrm{b}}$ \\
\hline & 70 & $6.76 \pm 0.29^{\mathrm{a}}$ & $2.68 \pm 0.42^{\mathrm{a}}$ & $24.21 \pm 0.36^{\mathrm{b}}$ & $15.38 \pm 0.10^{\mathrm{a}}$ & $0.16 \pm 0.00^{\mathrm{a}}$ & $3.17 \pm 0.09^{b}$ \\
\hline
\end{tabular}

All data are reported as the mean \pm SE $(n=5)$. Values marked same capital letter or lower case letter indicates that values were not significantly different among storage period for the same treatment $(\mathrm{p}>0.05)$. 


\section{전해질유출률 변화}

스트레스 조건하에서 ROS나 지질분해효소에 의한 세 포막의 인지질 및 불포화지방산의 지질과산화가 증가하 게 되면 세포막 유동성(membrane fluidity)의 감소 및 막투 과성(membrane permeability)의 증가 등을 수반하는 세포 막 손상이 일어나고, 그 결과 전해질유출이 증가하는 것으 로 알려져 있다(Kou 등, 2015). 따라서 본 연구에서 온도순 화처리에 따른 세포막의 견고성을 평가하고자 과피의 전 해질유출률을 조사한 결과는 Fig. 2 와 같다. 대조구와 온도 순화처리구 모두 저장기간 동안 증가추세를 보이기는 했 으나, 온도순화처리구에서는 유의적인 차이를 보이지 않 은 반면, 대조구에서는 저장 30 일까지 전해질유출률이 유 의적인 차이를 보이면 증가하는 것으로 나타났으며, 저장 20 일까지는 온도순화처리구의 전해질유출률이 대조구보 다 다소 높게 나타났다( $\mathrm{p}>0.05)$. 일반적으로는 전해질유출 률이 높을수록 과피갈변 또는 흑변의 발생률 또한 높은 것으로 알려져 있다(Sheng 등, 2016; Li 등, 2017). 그러나 본 연구에서 과피흑변 발생이 거의 완료되는 저장 30 일 이내의 과피흑변 발생률과 전해질유출률을 살펴보면, 과 피흑변 발생률이 현저히 낮았던 온도순화처리구의 전해 질유출률이 유의적인 차이는 없었으나, 대조구보다 조금 더 높게 나타나, 이전의 연구들과는 차이를 보였다. 이는 Lafta와 Fugate(2009)가 보고한 바와 같이 식물체의 건조로 인한 세포막의 손상에 의해 호흡량이 증가하고, 이로 인해 전해질유출률이 증가한 것으로 판단되며, 온도순화처리 구에서의 전해질유출률의 증가는 과피흑변 발생과 상관 관계가 낮은 것으로 보인다. 반면, 저장 30 일 이후부터는 온도순화처리구보다 대조구의 전해질유출률이 더 높게 나타났는데, 이는 $\mathrm{Ma}$ 등(2017)이 보고한 바와 같이 저온에

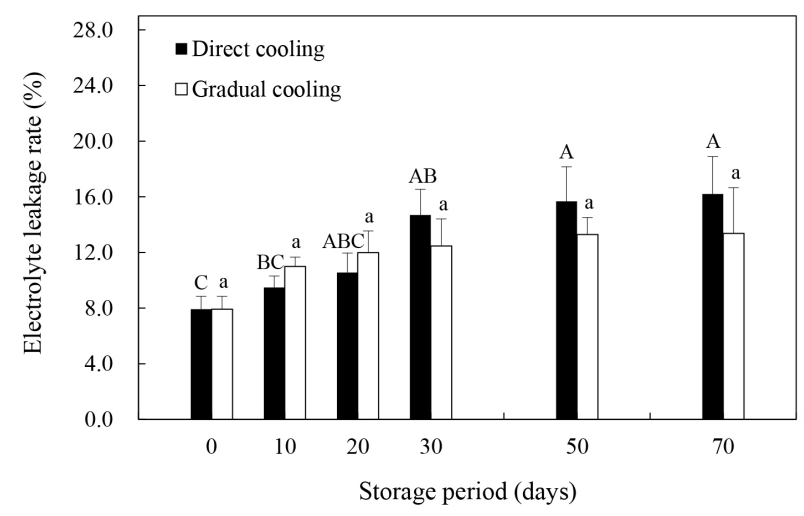

Fig. 2. Changes of electrolyte leakage rate in direct cooling and gradual cooling treated 'Chuhwang' pear fruit during 70 days of storage at $0^{\circ} \mathrm{C}$.

Bars marked same capital letter or lower case letter indicates that values were not significantly different among storage period for the same treatment $(\mathrm{p}>0.05)$.
민감한 특성을 갖고 있는 추황배를 수확 직후 $0^{\circ} \mathrm{C}$ 에 저장 하였을 때, 저장기간의 경과에 따른 저온스트레스에 기인 한 것으로 보인다. 따라서 저온에 민감한 품종의 경우, 수확 후 $0^{\circ} \mathrm{C}$ 에 바로 저장하는 것은 저온스트레스로 인한 세포막 손상과 이로 인한 전해질용출의 증가 및 과피흑변 의 발생을 촉진하는 요인이 될 수 있을 것으로 사료된다.

\section{수용성 탄수화물 및 총아스코르브산 함량 변화}

일반적으로 수확 시 추황배에 존재하는 주요 수용성 탄수화물은 유리당인 sucrose, hexose(glucose와 fructose) 및 당알코올인 sorbitol이며, 이들 중 sucrose와 sorbitol은 특정 효소의 작용에 의해 환원당인 glucose와 fructose로 전환될 수 있다(Sturn과 Tang, 1999). Fig. 3(A)의 처리방법 에 따른 sucrose 함량은 온도순화처리보다 대조구에서 높 게 유지되었으며, 저장 기간에 따라서는 대조구와 온도순 화처리 모두 저장 10 일에 수확 시 함량보다 증가하였으나, 저장 20 일부터는 감소하는 경향을 보였다. 대조구는 저장 기간이 경과함에 따라 서서히 감소한 반면, 온도순화처리 구는 저장 20 일에 저장 10 일 대비 $40.7 \%$ 의 큰 감소폭을 보였고, 그 후 비슷한 함량을 유지하였다. Glucose와 fructose의 합으로 나타낸 hexose 함량(Fig. 3B)은 저장기간 의 경과에 따라 유의적인 차이를 보이지 않았던 대조구와 는 달리, 온도순화처리구에서는 저장 기간 동안 유의적으 로 증가하는 것으로 나타났다 $(\mathrm{p}<0.05)$. 식물체에서 유리당 은 과일의 향이나 영양가, 저온과 osmotic stress에 대한 내성, 산화적 스트레스에 대한 보호작용 및 유전자 발현의 조절 등과 밀접한 관련이 있는 것으로 알려져 있다(Couee 등, 2006; $\mathrm{Yu}$ 등, 2017). 이 중 유리당의 저온 내성에 관한 연구들은 과일의 종류나 품종에 따라 작용하는 유리당의 종류는 다르지만, 높은 유리당 함량에 의해 저온내성이 증가함으로써 저온장해(chilling injury)를 감소시킬 수 있 다고 알려져 있다. Cao 등(2013)은 비파 중 다른 품종에 비해 저온에 대한 내성이 높았던 'Ninghaibai' 품종에서 상대적으로 hexose 함량이 높았다고 보고하였으며, Wang 등(2016) 또한 oxalic acid를 처리한 살구에서 glucose와 fructose를 증가시키는 효소의 활성이 증가하여 hexose 함 량이 증가함으로써 저온에 대한 내성이 증가하였다고 보고 하였다. 반면, Holland 등(2002)은 열처리를 통해 'Fortune' 만다린의 sucrose 함량이 증가함으로써 저온에 대한 내성 이 증가하였다고 하였으며, $\mathrm{Yu}$ 등(2017)은 1-MCP처리한 복숭아에서 저온저장 중 sucrose 분해가 억제됨으로써 sucrose 함량이 상대적으로 높게 유지된 품종에서 저온에 대한 내성이 더 높게 나타났다고 보고하였다. 본 연구에서 유리당의 변화양상을 종합해 보았을 때, 비파나 살구와 같이 sucrose 함량보다는 저온저장 중 증가한 hexose에 의 해 추황배의 저온내성이 증가하였고, 대조구보다 환원당 

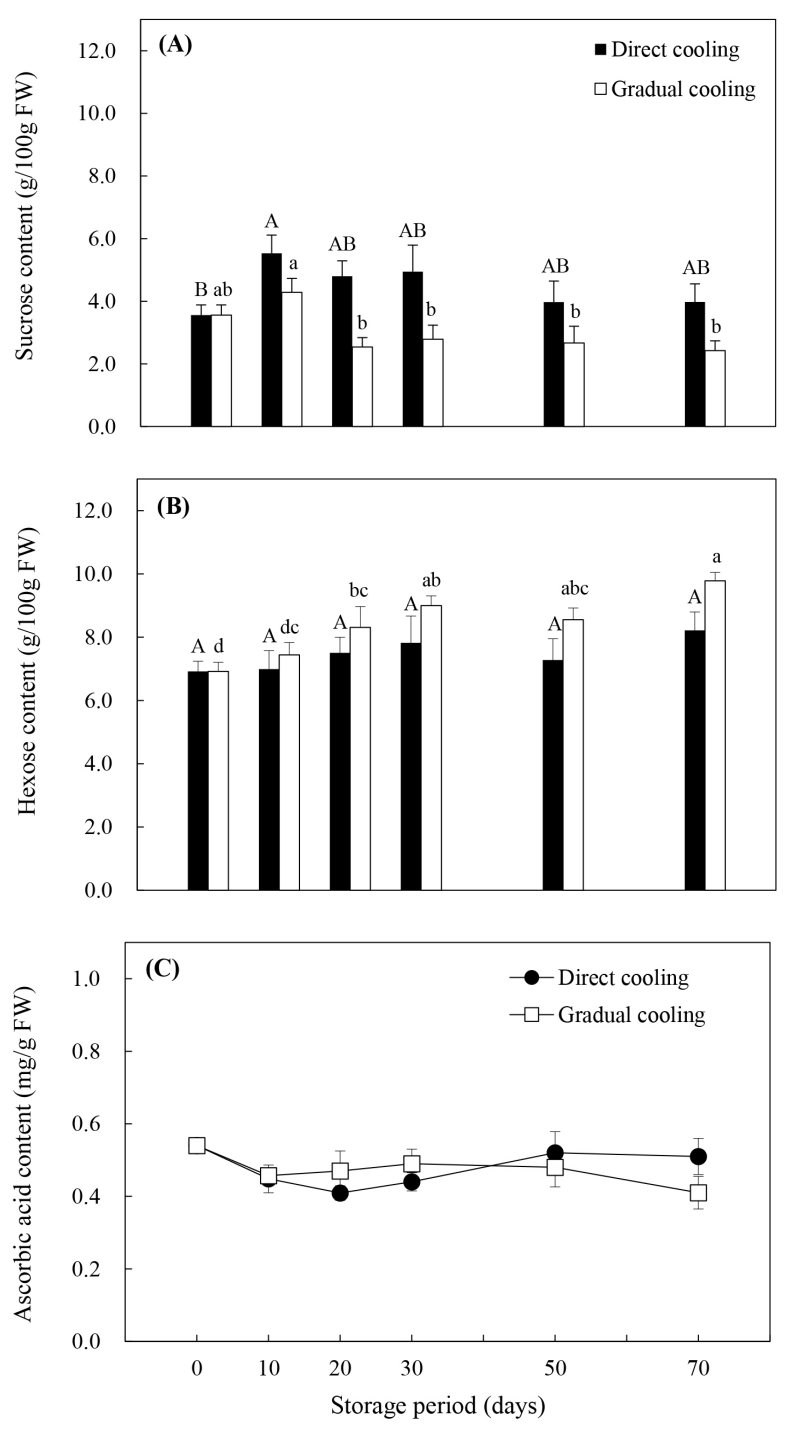

Fig. 3. Changes of sucrose (A), hexose (B), and ascorbic acid content (C) in direct cooling and gradual cooling treated 'Chuhwang' pear fruit during 70 days of storage at $0^{\circ} \mathrm{C}$.

Bars marked same capital letter or lower case letter indicates that values were not significantly different among storage period for the same treatment $(\mathrm{p}>0.05)$.

함량이 높았던 온도순화처리구의 저온내성이 상대적으로 높게 유지되면서 과피흑변 발생률 또한 낮게 나타난 것으 로 판단된다.

Hexose는 또한 아스코르브산이나 카로티노이드와 같은 항산화물질의 전구물질을 제공함으로써 항산화 방어기작 에 있어서 중요한 작용을 하는 것으로 알려져 있으며 (Couee 등, 2006), 이들 중 아스코르브산은 대표적인 항산 화 성분 중의 하나이다. Fig. $3 \mathrm{C}$ 와 같이, 대조구의 아스코르 브산 함량은 저장 20 일까지는 감소하였으나, 30 일 이후 약간 증가추세를 보인 반면, 온도순화처리구는 저장 기간
이 경과함에 따라 감소하는 경향을 보였다. 대조구와 비교 했을 때 저장 30 일까지는 온도순화처리에서 다소 높은 함량을 보였으나, 저장 50 일 후에는 급격하게 감소하면서 대조구보다 낮은 함량을 나타냈다. 아스코르브산은 여러 가지 비효소적 또는 효소적 반응에 관여하여 항산화 작용 을 나타내는데, 특히 유해한 과산화수소 $\left(\mathrm{H}_{2} \mathrm{O}_{2}\right)$ 를 물분자 로 전환시키는 $\mathrm{APX}$ 효소의 반응 과정에서 전자공여체 (electron donor)로 작용하거나, 지질과산화에 의해 생성된 반응성이 강한 라디칼들과 결합함으로써 산화적 스트레 스로부터 식물세포를 보호하는 데 중요한 역할을 하는 것으로 알려져 있다(Lechaudel 등, 2013). 또한, Wang (1996)은 저온저장 전 온도처리가 아스코르브산 함량에 영향을 줌으로써 저온내성을 증가시킬 수 있다고 보고하 였는데, 저온에 민감한 zucchini squash를 대상으로 $15^{\circ} \mathrm{C}$ 에 서 2 일간 온도처리한 후 저장했을 때, 아스코르브산 함량 이 높게 유지되고, 저온장해 발생률도 낮게 나타났다고 보고한 바 있다. 본 연구에서도 저온저장 30 일까지 온도순 화처리구의 아스코르브산 함량이 대조구보다 다소 높게 나타났는데, 이는 저온저장 초기에 $\mathrm{APX}$ 의 작용을 돕거나 지질과산화 중 생성된 라디칼들을 제거해줌으로써 과피 흑변 발생을 억제시키는 데 영향을 주었을 것으로 추정된 다.

\section{총폴리페놀 함량 및 polyphenol oxidase 활성 변화}

폴리페놀은 항산화물질로서 ROS에 대한 보호작용을 함과 동시에, $\mathrm{PPO}$ 와 함께 효소적 갈변에 관여하는 것으로 알려져 있으며, 이에 따라 총폴리페놀 함량과 PPO 활성은 과피흑변 연구에서 주요하게 다루어지고 있는 요인들이 다. 저장기간에 따른 총폴리페놀 함량(Fig. 4A)의 변화를 살펴보면, 대조구는 저장 30 일까지 수확 시 함량인 5.69 $\mathrm{mg} \mathrm{CAE} / \mathrm{g} \mathrm{FW}$ 보다 낮은 함량을 보이다가 저장 50 일 이후 약간 증가하기는 했으나, 저장 기간에 따른 유의적인 차이 를 보이지 않았다 $(\mathrm{p}<0.05)$. 반면, 온도순화처리구는 처리 종료 시 $6.07 \mathrm{mg} \mathrm{CAE} / \mathrm{g} \mathrm{FW}$ 로 약간 증가하였고, 저장 70 일 에는 $6.88 \mathrm{mg} \mathrm{CAE} / \mathrm{g} \mathrm{FW}$ 로 저장 기간 내내 증가추세를 보였으며, 이는 온도순화처리 및 저장기간의 경과에 따른 수분함량의 감소에 의한 것으로 보인다(Zhang 등, 2003). 처리방법에 따른 폴리페놀 함량은 저장기간 내내 온도순 화처리구에서 높게 유지되었으며, 이로 인해 온도순화처 리구의 항산화능이 증가됨으로써 과피흑변 발생의 감소 에 도움을 주었을 것으로 판단된다.

Fig. 1에서 살펴본 바와 같이 처리방법에 따라 과피흑변 발생률은 현저한 차이를 보였으나, 대조구와 온도순화처 리구의 PPO 활성은 유의적인 차이를 보이지 않았다. 그러 나 과피흑변 발생이 급격하게 증가했던 저장 30 일까지의 $\mathrm{PPO}$ 활성의 변화양상은 처리방법에 따라 다르게 나타났 

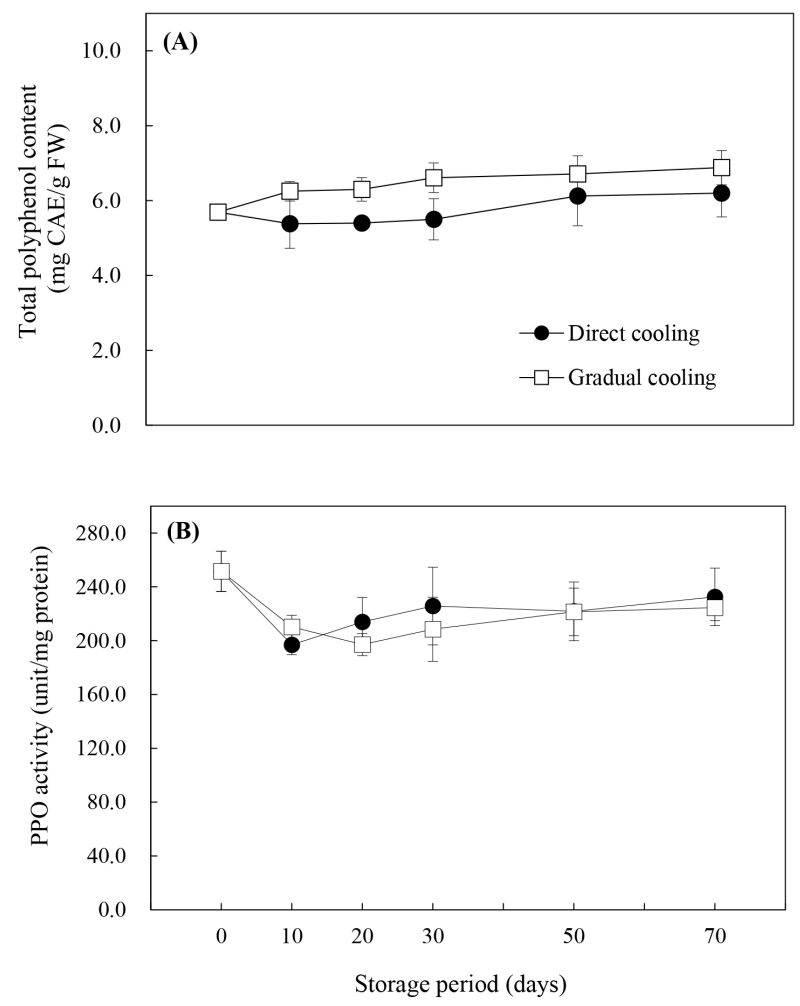

Fig. 4. Changes of total polyphenol content (A) and polyphenol oxidase (PPO) activity (B) in direct cooling and gradual cooling treated 'Chuhwang' pear fruit during 70 days of storage at $0^{\circ} \mathrm{C}$.

다(Fig. 4B). 대조구와 온도순화처리구 모두 저장 10 일에는 초기값보다는 낮은 값을 보였으나, 저장 10 일 이후로는 대조구의 PPO 활성이 증가하면서 온도순화처리구보다 높 게 나타났으며, 온도순화처리구는 저장 20 일까지는 감소 하다가 30 일부터 서서히 증가하는 경향을 보였다. 대조구 에서의 PPO 활성이 높게 나타난 것은 Yan 등(2013)이 냉각 속도가 PPO 활성에 미치는 영향에 대해 보고한 바와 같이, 수확 후 $0^{\circ} \mathrm{C}$ 에 바로 저장하는 급속냉각방식은 $12^{\circ} \mathrm{C}$ 에서 시작하여 5 일마다 $2^{\circ} \mathrm{C}$ 씩 온도를 내려 총 30 일에 걸쳐 서서 히 냉각한 후 $0^{\circ} \mathrm{C}$ 에 저장하는 냉각방식에 비해 $\mathrm{PPO}$ 활성과 $\mathrm{PPO}$ 관련 유전자의 발현을 증가시키기 때문으로 보인다. 온도처리 외에도 $\mathrm{Kou}$ 등(2015)은 $\mathrm{CaCl}_{2}$ 나 다당류 중합체 의 일종인 pullulan 등의 처리에 의해 총폴리페놀의 분해가 지연되고, $\mathrm{PPO}$ 활성이 억제됨으로써 배의 갈변이 감소하 였다고 보고하였으며, Ma 등(2017) 또한 'Huangguan'배에 $5 \mathrm{ppm}$ 농도로 에틸렌을 처리했을 때 폴리페놀의 생합성을 자극하여 총폴리페놀 함량이 높게 유지되고, $\mathrm{PPO}$ 활성부 위의 $\mathrm{Cu}^{2+}$ 에 작용하여 활성을 억제시킴으로써 과피갈변이 효과적으로 억제되었다고 보고하였다. 따라서 높은 폴리 페놀 함량과 낮은 PPO 활성은 과피흑변 발생률 저하와
상관관계가 높은 것으로 판단된다.

\section{DPPH radical scavenger activity 변화}

Allan 등(2006)은 저온 등의 스트레스 조건하에서 식물 체의 반응에 의해 ROS는 증가할 수 있으며, 증가한 ROS는 세포손상을 일으키는 부정적 요인으로 작용하거나 또는 항산화 방어기작을 활성화시킴으로써 저온 손상으로부터 식물세포를 보호하는 작용을 한다고 보고하였다. 본 연구 에서는 식물체의 항산화 방어기작이 과피흑변 발생에 미 치는 영향을 알아보기 위해 DPPH 라디칼 소거능을 이용 하여 온도순화처리 및 저온저장에 따른 비효소적 항산화 능을 평가하였다(Fig. 5). 저장 기간의 경과에 따른 추황배 과피의 라디칼 소거능은 처리방법에 따라 약간의 차이를 보였다. 과피흑변 발생률이 높았던 대조구의 경우, 저장 10 일에 $30.79 \mu \mathrm{M} \mathrm{TE} / \mathrm{g} \mathrm{FW}$ 이었던 소거능이 저장 20 일 이후 부터는 $27.28-27.80 \mu \mathrm{M} \mathrm{TE} / \mathrm{g} \mathrm{FW}$ 정도로 감소하였는데, 이는 저온처리에 의해 DPPH 라디칼 소거능이 감소하고, 이러한 항산화 활성의 감소는 저온민감도를 증가시킨다 고 보고한 Kang과 Saltveit(2002)의 연구결과와 유사한 것 으로, 낮은 항산화 활성에 의한 저온민감도의 증가가 대조 구에서의 과피흑변 발생을 증가시킨 것으로 판단된다. 반 면에, 온도순화처리구는 저장 10 일에 $33.72 \mu \mathrm{M} \mathrm{TE} / \mathrm{g} \mathrm{FW}$ 정도의 소거능을 보이다가 저장 50 일에 $35.61 \mu \mathrm{M} \mathrm{TE} / \mathrm{g}$ $\mathrm{FW}$ 까지 증가하는 것으로 나타나, 대조구보다 높은 항산화 활성을 보였다( $>00.05)$. 온도순화처리한 추황배의 $\mathrm{DPPH}$ 라디칼 소거능이 높게 나타난 것은 Fig. 4(A)와 같이 온도 순화처리구의 총폴리페놀의 함량이 더 높기 때문으로 보 이며, 이와 관련하여 Wang 등(2014)과 Liaudanskas 등

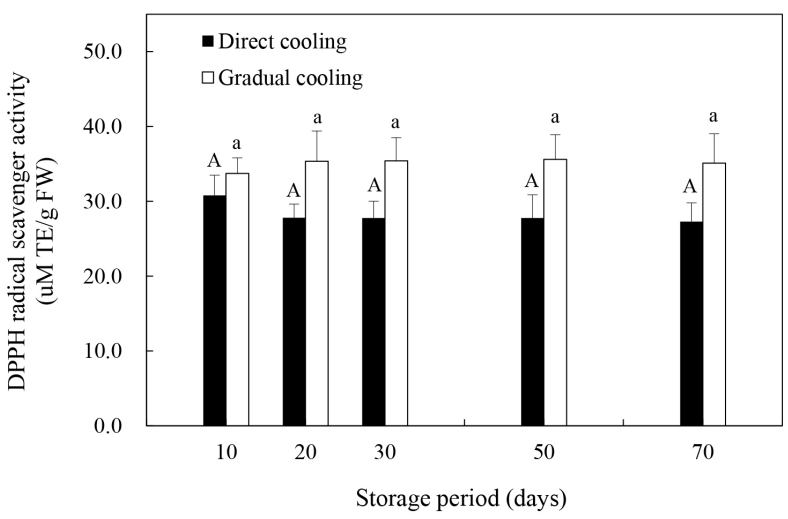

Fig. 5. Changes of DPPH radical scavenger activity in direct cooling and gradual cooling treated 'Chuhwang' pear fruit during 70 days of storage at $0^{\circ} \mathrm{C}$.

Bars marked same capital letter or lower case letter indicates that values were not significantly different among storage period for the same treatment $(p>0.05)$. 
(2017)은 저장 중 축적된 총폴리페놀 함량은 식물의 항산 화 활성의 증진과 정의 상관관계를 나타낸다고 보고한 바 있다.

\section{지질과산화물(TBARS) 및 lipoxygenase의 활성 변화}

Malondialdehyde(MDA)는 지질과산화의 최종산물로서 산화적 스트레스에 의한 세포막의 지질과산화를 평가하 는 지표성분이며 thiobarbituric acid(TBA)와의 반응을 이용 하여 함량을 구하는 것이 일반적이다. 그러나 TBA는 탄수 화물 특히 fructose와 발색반응을 일으키는 것으로 알려져 있어(Guillen-Sans와 Guzman-Chozas, 1998), 본 연구에서 는 fructose 함량이 높은 추황배의 특성을 고려하여 $\mathrm{MDA}$ 대신 TBARS 함량으로 지질과산화물을 나타냈다. 수확 시 TBARS 함량은 $13.8 \pm 0.6 \mu \mathrm{mol} / \mathrm{g} \mathrm{FW}$ 이었으며, 저장 기간 이 경과함에 따라 증가하는 것으로 나타났다(Fig. 6A). 처 리방법에 따른 TBARS 함량의 변화는 대조구는 $0{ }^{\circ} \mathrm{C}$ 저장 30 일까지 급격하게 증가하다, 저장 50 일 이후부터는 큰 변화를 보이지 않은 반면, 온도순화처리구는 저장 기간 동안 처리 종료 시의 $18.8 \pm 1.1 \mu \mathrm{mol} / \mathrm{g} \mathrm{FW}$ (data not shown)와
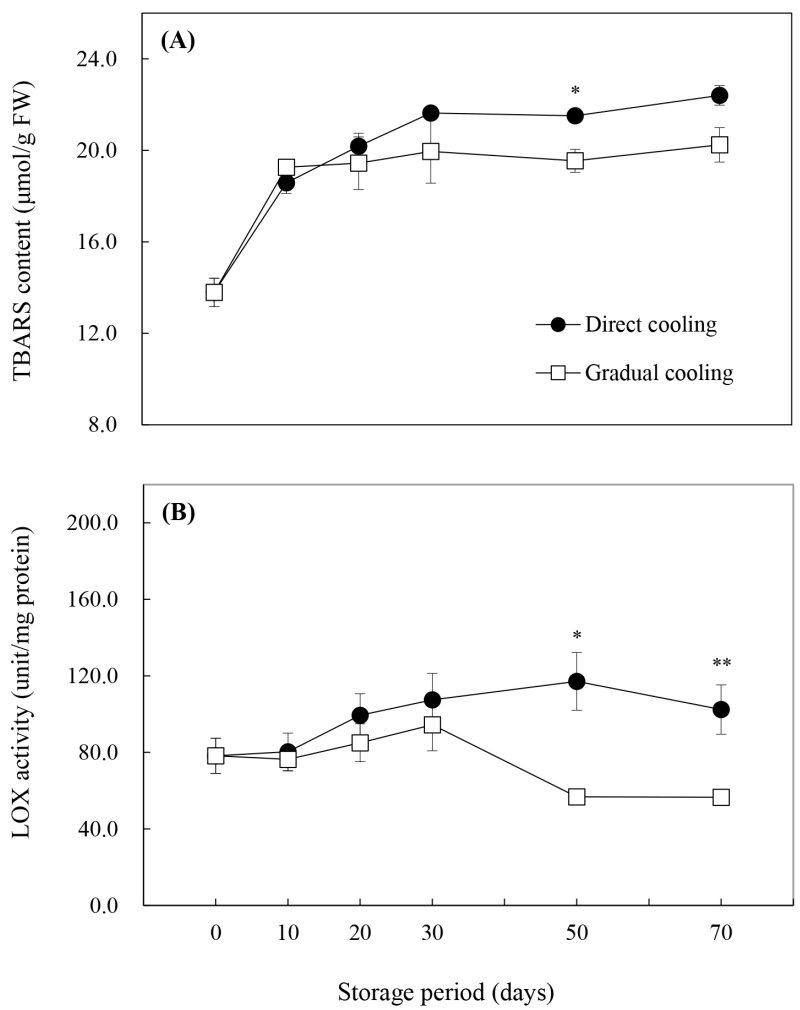

Fig. 6. Changes of TBARS value (A) and lipoxygenase (LOX) activity (B) in direct cooling and gradual cooling treated 'Chuhwang' pear fruit during 70 days of storage at $0^{\circ} \mathrm{C}$.

Significance differences were compared between treatment groups at $\mathrm{p}<0.05$ and $\mathrm{p}<0.01$ using the student's t-test.
유사한 값을 유지하였으며( $\mathrm{p}>0.05)$, 대조구보다는 낮은 함 량을 나타냈다. Imahori 등(2008)은 저온에 민감한 식물의 경우 저온저장 시 지질과산화가 증가한다고 보고하였는 데, 이는 대조구에서 저장 30 일까지 TBARS 값이 급격하게 증가하고, 과피흑변 발생률이 높게 나타난 것과 관련이 있을 것으로 판단된다. 또한, Maalekuu 등(2006)은 원예산 물의 수분손실은 세포막의 견고성 손실, LOX 효소의 활성 증가 및 세포막의 지질과산화 등과 정의 상관관계를 갖는다 고 보고한 바 있다. 따라서 온도순화처리 종료 후 TBARS 함량의 급격한 증가는 저온에 의해 지질과산화가 유도된 대조구와는 달리 Table 1 에 나타낸 바와 같이 온도순화처리 에 따른 수분손실( $4.62 \%$ 중량감소)에 의한 것으로 보인다.

Phospholipase D(PLD), lipase와 함께 세포막에 존재하는 지질분해효소인 LOX는 세포막의 불포화지방산을 분해하 여 ROS 등의 산화물을 생성하는 지질과산화 반응을 일으 키기 때문에 TBARS 함량과 밀접한 상관관계를 갖고 있는 것으로 알려져 있으며(Zhang 등, 2018), 본 연구에서도 LOX 활성은 TBARS 함량의 변화와 유사한 경향을 보였다. Fig. 6B)에서 수확 시 LOX 활성은 $75.9 \pm 3.9$ unit $/ \mathrm{mg}$ protein 이었으며, 대조구는 저장 70 일을 제외하고는 저장 10 일 이후부터 효소활성이 꾸준히 증가하는 것으로 나타났다. 반면에, 온도순화처리 종료 시 LOX 활성은 $73.9 \pm 11.7$ unit/mg protein으로 수확 시와 비교했을 때 약간 감소하기 는 했으나 유의적인 차이를 보이지 않았으며, 저온저장 30 일까지 서서히 증가하다가 저장 50 일 이후 급격하게 감소하면서 대조구와 유의적인 차이를 나타냈다 $(\mathrm{p}<0.05$, $\mathrm{p}<0.01)$. 일반적으로, $\mathrm{LOX}$ 의 활성 증가는 세포막의 구조 적 변화를 일으킴으로써 세포막의 구획화(compartmentalization)를 파괴하여 수분손실뿐만 아니라, 과피에서의 효소적 갈변을 증가시키는 것으로 알려져 있다(Maalekuu 등, 2005; Kanjuga, 2008; Sheng 등, 2016). Li 등(2017) 또한 'Huangguan'배를 $10^{\circ} \mathrm{C}, 3$ 일간 온도처리한 후 $0^{\circ} \mathrm{C}$ 에 저장했 을 때, 저장 초반보다는 저장 기간이 경과함에 따라 대조구 대비 과피갈변, $\mathrm{LOX}$ 활성 및 지질과산화물인 $\mathrm{MDA}$ 함량 에서 유의적인 감소가 나타났다고 보고하였다. 따라서 저 온저장 전 온도순화처리는 $0^{\circ} \mathrm{C}$ 에 바로 저장하는 것보다 $\mathrm{LOX}$ 의 활성을 감소시켜 세포막의 지질과산화를 억제시 키는 것으로 보인다. 그러나 세포막의 지질과산화는 LOX 뿐 아니라, PLD나 lipase와 같은 효소의 영향도 받으므로 이들 효소의 작용에 대한 추가적인 연구가 필요할 것으로 판단된다.

\section{항산화 관련 효소의 활성 변화}

과일은 일반적인 발달(development), 숙성(ripening) 및 대사과정에서도 ROS를 생성하며, 효소적 및 비효소적 항 산화체계를 이용하여 ROS를 제거하면서 세포내의 항산 
화 체계와 ROS 사이의 균형을 유지한다. 그러나 여러 가지 스트레스 환경에 노출되면 과량의 ROS가 축적되면서 항 산화-ROS 사이의 균형이 깨지게 되고, 이로 인해 여러 가지 생리장해가 발생하게 된다(Kumar 등, 2016; Ma 등, 2017). 효소적 항산화체계에 해당하는 SOD, APX, CAT 및 POD 와 같은 효소들은 ROS를 제거하여 세포막의 견고성이 손상되지 않도록 보호해 줌으로써 과일과 채소의 갈변을 방지하는 것으로 알려져 있다(Kou 등, 2015; Ma 등, 2017).

항산화효소의 활성은 Fig. 7과 같다. SOD 효소는 활성산 소종인 superoxide 라디칼 $\left(\mathrm{O}_{2}{ }^{-}{ }^{-}\right)$에 작용하여 $\mathrm{H}_{2} \mathrm{O}_{2}$ 를 생성 하며, 유해한 $\mathrm{H}_{2} \mathrm{O}_{2}$ 는 $\mathrm{APX}, \mathrm{CAT}$ 및 $\mathrm{POD}$ 에 의해 즉각적으 로 무해한 물분자로 분해된다(Gill과 Tuteja, 2010). Fig. 7(A)에서와 같이 SOD의 활성은 대조구와 온도순화처리구 모두 저장 기간이 경과함에 따라 유의적으로 감소하였으 며 $(\mathrm{p}<0.05)$, 온도순화처리구의 활성이 대조구보다 낮게 나 타났다. Fig. 7(B)의 CAT 활성의 경우, 대조구는 저온저장 30 일까지는 급격하게 감소하다가 50 일부터는 큰 변화를 보이지 않았으며, 온도순화처리구는 저장 20 일까지는 대 조구보다 더 낮은 효소활성을 보이며 급격하게 감소하다 가, 저장 30 일 이후에 증가하면서 대조구보다 약간 높은
활성을 유지하는 것으로 나타났다( $\mathrm{p}>0.05) . \mathrm{APX}$ 의 활성 (Fig. 7C)은 두 처리구가 거의 동일한 값을 보였으며, 저장 20 일까지는 약간의 감소 추세를 보이다가 30 일 이후부터 는 활성의 변화가 거의 나타나지 않았다. 마지막으로 항산 화 효소 중 $\mathrm{POD}$ 의 활성(Fig. $7 \mathrm{D})$ 은 대조구의 경우, 저장 20 일을 제외하고는 초기치보다 낮은 활성을 보였으며, 온 도순화처리구는 CAT 활성과 유사한 경향을 보였다. 저장 20 일까지는 초기치보다 효소활성이 감소하면서 대조구보 다 오히려 낮은 활성을 보였으나, 저장 20 일 이후로는 저장 기간의 경과에 따라 효소 활성도 증가하였는데, 이는 Chongchatuporn 등(2013)이 보고한 것처럼 저장기간이 경 과함에 따라 저온에 적응함으로써 저온내성이 증가하였 기 때문으로 해석할 수 있다.

Fig. 1 에서 살펴본 바와 같이 온도순화처리에 의해 과피 흑변 발생은 현저히 감소하였으나, 과피흑변이 급격하게 발생하는 저장 30 일까지의 항산화효소들의 활성변화를 보면 대조구와 온도순화처리구간에 유의적인 차이는 보 이지 않았다. 일반적으로 저온내성이 높은 품종은 저장 온도에 따라 항산화효소의 활성이 큰 영향을 받지 않으나, 저온내성이 낮은 즉, 저온에 민감한 품종의 경우는 저장

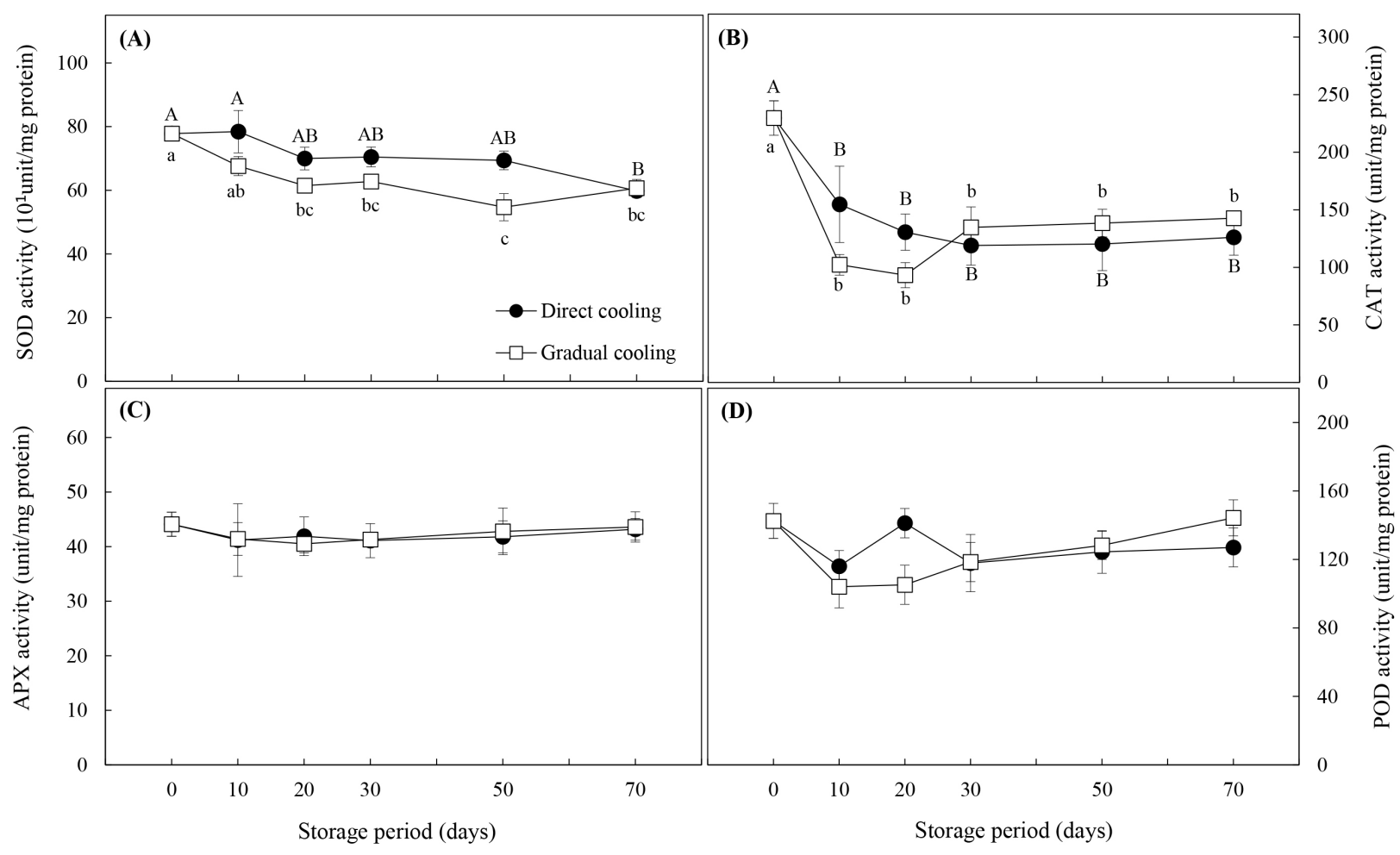

Fig. 7. Changes of activities of superoxide dismutase (SOD, (A)), catalase (CAT, (B)), ascorbate peroxidase (APX, (C)), and peroxidase (POD, (D)) in direct cooling and gradual cooling treated 'Chuhwang' pear fruit during 70 days of storage at $0^{\circ} \mathrm{C}$.

Values marked same capital letter or lower case letter indicates that values were not significantly different among storage period for the same treatment $(\mathrm{p}>0.05)$. 
온도가 낮아질수록 항산화효소의 활성이 감소하고, 이로 인해 저온장해 발생률이 높은 것으로 알려져 있다 $(\mathrm{Lim}$ 등, 2009). 따라서 저온민감성을 가진 원예산물의 온도저 항성(thermotolerance)을 증진시켜 저장성을 높이기 위한 연구들이 많이 보고되고 있으며, 이들 중에는 저온저장 전 고온이나 저온 등의 온도처리를 활용한 경우가 많다. 감귤 중 'Fortune' 품종 대상 $37^{\circ} \mathrm{C}$ 열처리(Sala와 Lafuente, 1999) 및 $53^{\circ} \mathrm{C}$ 열수처리(Sala와 Lafuente, 2000), 'Satsuma' 품종 대상 $50^{\circ} \mathrm{C}$ 열수처리(Ghasemnezhad 등, 2008)는 저온 저장 시 항산화효소 특히 CAT의 활성을 증진시켜 저온에 대한 내성을 높이는 것으로 알려져 있다. 또한, 'Huangguan' 배의 $10^{\circ} \mathrm{C}, 3$ 일 처리 $\left(\mathrm{Li}\right.$ 등, 2017) 및 망고의 $12^{\circ} \mathrm{C}, 1$ 일 처리 (Zhang 등, 2017) 등 저온처리를 이용한 실험에서도 저온처 리에 의한 항산화효소의 활성증가와 저온내성 간에는 정 의 상관관계가 있는 것으로 나타났다. 그러나 Hodges 등 (2004)은 저온에 대한 내성은 항산화 효소의 활성에 의해 서만 결정되는 것은 아니며, 원예산물이 보유하고 있는 항산화물질의 함량이나 스트레스 조건에 노출되었을 때 생성되는 항산화물질 또는 ROS의 발생량 등에 의해 영향 을 받는다고 보고하였다.

이상의 결과를 종합해 보면 온도순화처리에 의해 항산 화효소의 활성이 유의적으로 증가하지 않았음에도 과피 흑변 발생이 효과적으로 억제된 것은 효소적 방어기작 보다는 비효소적 항산화 방어기작에 의한 것으로, 온도순 화처리에 의해 지질과산화효소의 활성이 억제되고, hexose, 총폴리페놀과 같은 항산화물질 및 $\mathrm{DPPH}$ 라디칼 소거능이 증가하면서 추황배의 저온 민감도(chilling sensitivity)가 감 소하고, 이로 인해 과피흑변 발생이 효과적으로 억제된 것으로 판단된다.

\section{요 약}

본 연구는 만개 후 187 일에 수확한 추황배를 대상으로 $0^{\circ} \mathrm{C}$ 저온저장 전 온도순화처리가 과피흑변 발생 및 생리화 학적 변화에 미치는 영향을 살펴보았다. 온도순화처리 종 료 시 $4.62 \%$ 의 중량감소가 발생하였으며, 두 처리구 모두 저온저장 30 일 경과 시 과피흑변 발생은 거의 완료되었으 며, 온도순화처리구의 과피흑변 발생률은 $13.9 \%$ 로 대조구 $72.2 \%$ 에 비해 유의적으로 감소하였다. 대조구와 비교했을 때, 온도순화처리에 의해 과피의 총색도와 경도가 약간 낮게 나타나고, 전해질유출률과 호흡량은 약간 높게 나타 났으나, 식미적인 품질에는 차이를 보이지 않았다. 과피흑 변이 활발하게 발생하는 저장 30 일까지의 생화학적 변화 를 보면, 대조구에 비하여 온도순화처리구의 경우 sucrose 함량은 저장기간의 경과에 따라 감소하였고, 아스코르브 산, hexose, 총폴리페놀 함량 및 DPPH 라디칼 소거능은
증가하였으며, 대조구보다 높은 값을 나타내었다. $\mathrm{PPO}$ 의 활성과 지질과산화와 관련된 TBARS 함량과 LOX 활성은 대조구보다 낮게 나타났으며, 항산화 효소의 활성은 처리 에 따른 유의적인 차이를 보이지 않았다. 따라서 아스코르 브산, hexose, 총폴리페놀과 같은 항산화물질의 함량 증가, $\mathrm{DPPH}$ 라디칼 소거능의 증가, 지질과산화 및 항산화 관련 효소들의 활성변화를 종합해 볼 때, 수확 후 $0^{\circ} \mathrm{C}$ 저장 전 온도순화처리는 추황배의 저온 민감도를 낮추어 과피흑 변 발생을 감소시킬 수 있는 효과적인 방지 기술이 될 것이라 생각된다.

\section{감사의 글}

본 연구는 농촌진흥청 연구사업(과제번호: PJ012732) 및 2019년도 농촌진흥청(국립원예특작과학원) 전문연구 원 과정 지원 사업에 의해 이루어진 것임.

\section{Conflict of interests}

The authors declare no potential conflict of interest.

\section{ORCID}

Mi-Hee Choi https://orcid.org/0000-0002-9640-6819 Byung-Seon Lim https://orcid.org/0000-0001-6221-7967

\section{References}

Allan AC, Maddumage R, Simons JL, Neill SO, Ferguson B. Heat-induced oxidative activity protects suspensioncultured plant cells from low temperature damage. Funct Plant Biol, 33, 67-76 (2006)

Cao S, Yang Z, Zheng Y. Sugar metabolism in relation to chilling tolerance of loquat fruit. Food Chem, 136, 139-143 (2013)

Choi JH, Choi JJ, Yim SH, Cho YS, Lee HC, Jung SK, Choi HS. Effect of paper bag types on the fruit quality, occurrence of skin blackening and comstock mealybug of 'Chuhwangbae' pear fruit. Korean J Intl Agri, 25, 50-55 (2013)

Choi JH, Yim SH, Kim SJ, Kwon YH, Lee HC, Jung SK, Choi HS. Effect of paper bag types and harvesting dates on skin blackening and fruit quality of 'Chuhwangbae' pear trees. Korean J Organic Agri, 23, 91-101 (2015)

Chongchatuporn U, Ketsa S, Van Doorn WG. Chilling injury in mango (Mangifera indica) fruit peel: Rela- 
tionship with ascorbic acid concentrations and antioxidant enzyme activities. Postharvest Biol Technol, 86, 409-417 (2013)

Couee I, Sulmon C, Gouesbet G, Amrani AE. Involvement of soluble sugars in reactive oxygen species balance and responses to oxidative stress in plants. J Exp Bot, 57, 449-459 (2006)

Demidchik V. Mechanisms of oxidative stress in plants: From classical chemistry to cell biology. Environ Exp Bot, 109, 212-228 (2015)

Ghasemnezhad M, Marsh K, Shilton R, Babalar M, Woolf A. Effect of hot water treatments on chilling injury and heat damage in 'satsuma' mandarins: Antioxidant enzymes and vacuolar ATPase, and pyrophosphatase. Postharvest Biol Technol, 48, 364-371 (2008)

Gill SS, Tuteja N. Reactive oxygen species and antioxidant machinery in abiotic stress tolerance in crop plants. Plant Physiol Biochem, 48, 909-930 (2010)

Guillen-Sans R, Guzman-Chozas M. The thiobarbituric acid reaction in food; A review. Crit Rev Food Sci Nutr, 38, 315-330 (1998)

Hodges DM, Lester GE, Munro KD, Toivonen PMA. Oxidative stress: Importance for postharvest quality. Hortscience. 39, 924-929 (2004)

Holland N, Menezes HC, Lafuente MT. Carbohydrates as related to the heat-induced chilling tolerance and respiratory rate 'Fortune' mandarin fruit harvested at different maturity stages. Postharvest Biol Technol, 25, 181-191 (2002)

Imahori Y, Takemura M, Bai J. Chilling-induced oxidative stress and antioxidant responses in mume (Prunus mume) fruit during low temperature storage. Postharvest Biol Technol, 49, 54-60 (2008)

Kang HK, Lee SK. Effects of prestorage treatment by EDTA-Ca and heating on skin blackening and quality during cold storage in 'Niitaka' pear fruits. J Kor Soc Hort Sci, 44, 52-56 (2003)

Kang HK, Saltveit ME. Effect of chilling on antioxidant enzymes and DPPH-radical scavenging activity of highand low-vigour cucumber seedling radicles. Plant Cell Environ, 25, 1233-1238 (2002)

Kanjuga Z. Chilling response of plants: Importance of galactolipase, free fatty acids and free radicals. Plant Biol, 10, 171-184 (2008)

Kim SI, Sim KH, Ju SY, Han YS. A study of antioxidative and hypoglycemic activities of Omija (Schizandra chinensis Baillon) extract under variable extract conditions. Korean J Food Nutr, 22, 41-47 (2009)

Kou X, Wu M, Li L, Wang S, Xue Z, Liu B. Effects of $\mathrm{CaCl}_{2}$ dipping and pullulan coating on the development of brown spot on 'Huangguan' pears during cold storage. Postharvest Biol Technol, 99, 63-72 (2015)

Kumar V, Irfan M, Ghosh S, Chakraborty N, Chakraborty $\mathrm{S}$, Datta A. Fruit ripening mutants reveal cell metabolism and redox state during ripening. Protoplasma, 253, 581-594 (2016)

Lafta AM, Fugate KK. Dehydration accelerates respiration in postharvest sugarbeet roots. Postharvest Biol Technol, 54, 32-37 (2009)

Lechaudel M, Lopez-Lauri F, Vidal V, Sallanon H, Joas J. Response of physiological parameters of mango fruit (transpiration, water relations and antioxidant system) to its light and temperature environment. J Plant Physiol, 170, 567-576 (2013)

Lee EJ. Major metabolites involved in skin blackening of 'Niitaka' pear stored under cold temperature. Kor J Hort Sci Technol, 32, 359-365 (2014)

Lee UY, Wang MH, Bae TM, Kim SJ, Choi JH, Ahn YJ, Chun JP. Effects of pre-drying, delayed cooling, and carbon dioxide on skin blackening disorder in asian pear (Pyrus pyrifolia Nakai) 'Chuhwangbae'. Korean J Hortic Sci Technol, 36, 370-379 (2018)

Li D, Chenh Y, Dong Y, Shang Z, Guan J. Effects of low temperature conditioning on fruit quality and peel browning spot in 'Huangguan' pears during cold storage. Postharvest Biol Technol, 131, 68-73 (2017)

Liaudanskas M, Zymone $\mathrm{K}$, Viskelis J, Klevinskas A, Janulis V. Determination of the phenolic composition and antioxidant activity of pear extracts. J Chem, 2017, 1-9 (2017)

Lim CS, Kang SM, Cho JL, Gross KC. Antioxidizing enzyme activities in chilling-sensitive and chillingtolerant pepper fruit as affected by stage of ripeness and storage temperature. J Am Soc Hortic Sci, 134, 156-163 (2009)

Lin Y, Lin H, Lin Y, Zhang S, Chen Y, Jiang X. The roles of metabolism of membrane lipids and phenolics in hydrogen peroxide-induced pericarp browning of harvested longan fruit. Postharvest Biol Technol, 111, 53-61 (2016)

Ma Y, Yang M, Wang J, Jiang CZ, Wang Q. Application of exogenous ethylene inhibits postharvest peel browning 
of 'Huangguan' pear. Front Plant Sci, 7, 1-11 (2017)

Maalekuu K, Tuvia-Alkalai S, Shalom Y, Fallik E. Elkind Y, Jenks MA, Goodwin MS. Characterization of physiological and biochemical factors associated with postharvest water loss in ripe pepper fruit during storage. J Am Soc Hortic Sci, 130, 735-741 (2005)

Maalekuu K, Elkind Y, Leikin-Frenkel A, Lurie S, Fallik

E. The relationship between water loss, lipid content, membrane integrity and LOX activity in ripe pepper fruit after storage. Postharvest Biol Technol, 42, 248255 (2006)

Murshed R, Lopez-Lauri F, Sallanon H. Effect of water stress on antioxidant systems and oxidative parameters in fruits of tomato (Solanum lycopersicon L., cv. Microtom). Physiol Mol Biol Plants, 19, 363-378 (2013)

Park YM, Lee YJ. Ripening responses and quality changes of 'Fuyu' persimmon fruit as influenced by exogenous ethylene and subsequent short-term storage temperature. Kor J Hort Sci Technol, 24, 216-221 (2006)

Sala JM, Lafuente MT. Catalase in the heat-induced chilling tolerance of cold-stored hybrid Fortune mandarin fruits. J Agric Food Chem. 47, 2410-2414 (1999)

Sala JM, Lafuente MT. Catalase enzyme activity is related to tolerance of mandarin fruits to chilling. Postharvest Biol Technol, 20, 81-89 (2000)

Sheng L, Zhou X, Liu ZY, Wang JW, Zhou Q, Wang L. Changed activities of enzymes crucial to membrane lipid metabolism accompany pericarp browning in 'Nanguo' pears during refrigeration and subsequent shelf life at room temperature. Postharvest Biol Technol, 117, 1-8 (2016)

Sturn A, Tang GQ. The sucrose-cleaving enzymes of plants are crucial for development, growth and carbon partitioning. Trends Plant Sci, 4, 401-407 (1999)

Wang CY. Temperature preconditioning affects ascorbate anti- oxidant system in chilled zucchini squash. Postharvest Biol Technol, 8, 29-36 (1996)

Wang J, Jiang Y, Li G, Lv M, Zhou X, Zhou Q, Fu W, Zhang L, Chen Y, Ji S. Effect of low temperature storage on energy and lipid metabolism accompanying peel browning of 'Nanguo' pears during shelf life. Postharvest Biol Technol, 139, 75-81 (2018)

Wang Y, Luo Z, Huang X, Yang K, Gao S, Du R. Effect of exogenous gamma-aminobutyric acid (GABA) treatment on chilling injury and antioxidant capacity in banana peel. Sci Hortic, 168, 132-137 (2014)

Wang Z, Cao J, Jiang W. Changes in sugar metabolism caused by exogenous oxalic acid related to chilling tolerance of apricot fruit. Postharvest Biol Technol, 114, 10-16 (2016)

Yan S, Li L, He L, Liang L, Li X. Maturity and cooling rate affects browning, polyphenol oxidase activity and gene expression of 'Yali' pears during storage. Postharvest Biol Technol, 85, 39-44 (2013)

Yu L, Shao X, Wei Y, Xu F, Wang H. Sucrose degradation is regulated by 1-methycyclopropene treatment and is related to chilling tolerance in two peach cultivars. Postharvest Biol Technol, 124, 25-34 (2017)

Zhang YB, Bae MJ, An BJ, Choi HJ, Bae JH, Kim S, Choi C. Effect of antioxidant activity and change in quality of chemical composition and polyphenol compound during long-term storage. Korean J Food Sci Technol, 35, 115-120 (2003)

Zhang Z, Zhu Q, Hu M, Gao Z, An F, Li M, Jiang Y. Low-temperature conditioning induces chilling tolerance in stored mango fruit. Food Chem, 219, 76-84 (2017)

Zor T, Selinger Z. Linearization of the bradford protein assay increases its sensitivity: Theoretical and experimental studies. Anal Biochem, 236, 302-308 (1996) 